\title{
Addressing the Age-Old Question of Human Perfectibility in Daniel Defoe's Mere Nature Delineated: Or, a Body WITHout a Soul
}

\begin{abstract}
This article discusses the concern with the improvement or perfectibility of human nature in eighteenth-century English society and the necessity of its encouragement considering the prevalence of human degeneration at different levels: intellectual, moral, social, political or cultural. After a brief presentation of the philosophical and literary background of the perfectibility debates, we look into Daniel Defoe's literary representation of human improvement and degeneration in his Mere Nature Delineated: or, a Body without a Soul (1726). Defoe's pamphlet had its roots in a real case of human imperfection or degradation, namely in Peter the Wild Boy's story, which gave him the opportunity to criticize his contemporaries' vices and failures.
\end{abstract}

Key words

Feral child; noble savage; the fool; perfectibility; improvement; culture; nature; political satire

\section{Introduction}

In order to understand the connection between Peter's story and the topic of human (im)perfectibility, we must clarify who this character was. Peter the Wild Boy was a feral child who was found naked while wandering through the forests of Hanover in $1725^{1}$. Feral children have always caused a sensation because of their supposed human-animal condition. Also called "humanimals" (McFarland 2009: 251), feral children are human children raised by non-human animals (Payne and Rae Barbera 2010: 272). Taken to King George I's court, Peter's situ- 
ation attracted intense public and media attention and generated the production of pamphlets, poems, sermons, paintings and wax sculptures. Peter quickly became a celebrity in various spaces and discourses and his case enlivened debates about human nature, its possibilities, its imperfections and limits, the differences between humans and animals, education, ethical virtues and political degeneration. In fact, Peter's case puzzled scientists' knowledge of the human species or, as Richard Nash's book title indicates, their familiarity with the borders of human vs. animal identity (Nash 2003).

The eighteenth century showed intense preoccupation with the pursuit and "fantasy of improvement" (Davidson 2009: 58), culture and cultivation functioning as key-interests of philosophers, scientists and writers of the age. For them, the improvement of plants, animals and people was of equal concern. For example, Georgic narratives were numerous and represented a mode of writing especially associated with improvement and culture, more specifically with the improvement of nature by means of hard work. On the other hand, eighteenthcentury men also showed concerns about the limits of improvement.

Debates over the more prominent role of either nature or nurture continued well into the century, giving birth to various interpretations. Some saw habit or culture as second nature (Davidson 2009: 58), while inborn nature (conceived in eighteenth-century terms like blood or birth) was opposed to culture, which is more flexible, changeable and, therefore, more advantageous to man and his progress.

Quite paradoxically, although he displayed several types of disabilities, Peter offered a model of simplicity and naturalness which was in stark contrast to the characteristics of members of the noble groups. Ideas of human progress no longer relied on the claims of aristocratic superiority which was gradually replaced by the Georgian middle-class ideas of hard work, gentility, personal merit or politeness.

Various essays on the subjects of breeding, education, culture, and progress were written in the age, such as those of philosophers like La Mettrie, Maupertius, Hume, Locke, Diderot, and Rousseau. For many Enlightenment thinkers, it seemed compulsory that biological inheritance should be supplemented by the workings of education and culture. Likewise, many other writers believed that climate, habit and education amend the human being and that human character is substantially determined by instruction (Davidson 2009: 165).

In Peter's case, the efforts to improve his language and manners are illustrative of the eighteenth-century obsession with improvement. Breeding relied on education and upbringing as a means to pave man's way to accomplishment at professional and social levels, enabling him to become a member of the cultured elite of the age. Moreover, his spiritual nature was also improved by his baptism. First called in contemporary newspapers the Wild Boy of Hamelin, he was later baptized as Peter.

Daniel Defoe was also interested in the issue of human perfectibility and the imperfections of human nature. In his novels, for instance in Robinson Crusoe 
and Gulliver's Travels, themes like labour, colonization, human rights, race, human improvement or degeneration (Culea 2010: 669) prove this constant concern. In the same way, in his novels, Defoe also highlighted the relevance of practical education (Shinagel 1968: 136).

Peter's condition and that of other feral children discovered through the centuries still fascinate and bewilder scientists or people in general. Recent scientific documentaries present the history of feral children and the most famous cases identified until now, while still looking for scientific explanations for their human-animal nature. This controversial subject was the focus of a National Geographic documentary from 2009 entitled Is It Real? Feral Children ${ }^{2}$. Similarly, various recent disciplines, such as developmental psychology or cognitive science, have emphasized the importance of education and human interaction in early stages of life.

\section{Human perfectibility in Daniel Defoe's Mere Nature Delineated: or, a Body Without a Soul}

Peter's case gave rise to the creation of numerous pamphlets, poems and sermons in the age of Enlightenment (Nash 2003: 42-43). For example, John Arbuthnot and Jonathan Swift satirized the public obsession with Peter's case in their coauthored satire The Most Wonderful Wonder that Ever Appeared to the Wonder of the British Nation (1726) ${ }^{3}$ and it may be that Peter's case also exerted a stimulating influence for Swift's Gulliver's Travels. Daniel Defoe produced a book-length satire, Mere Nature Delineated: or, a Body without a Soul (1726) .

According to recent findings ${ }^{5}$, Peter may have suffered from the Pitt-Hopkins Syndrome, a rare genetic condition with severe neurological effects leading to speech, learning and developmental difficulties. Defoe himself anticipated that Peter may have been afflicted by a disease unknown at that time, which could have obstructed the normal maturation of his natural capacities. Both his countenance and inability to speak may have accounted for this condition. He "looks wild and awkward, like one that has not formed his mouth yet, that does not know how to look, and, indeed, having no speech, he seems to look dumb" (57).

Each of the five parts offered Defoe the possibility to make use of Peter's story and satirize the flaws and vices of his contemporary society and even of humankind. However, the text spurred more general ideas related to the nature of the human mind or aspects concerning the degeneration of humanity, reaching a point in which the author doubts the very humanity of humans (Lamb 2004: 132).

Peter's case seemed the suitable pretext for Defoe to reflect the society's dumbness, wildness, folly and sickness, lamenting the deterioration of the nobility, courtiers, statesmen and politicians in general. Defoe brought to surface a troubling question: were the members of the civilized society the perfection of human nature or could it be that the poor innocent wild men or even the animals were better than humans? In Enlightenment culture, the bestialization of human- 
ity and the salvation or humanization of the beast (Fudge 2004: 11) seemed to reflect this tendency. For this reason, social, cultural, and political criticism as well as criticism regarding the dejected state of the civilized individual is interwoven everywhere in the text.

\subsection{Peter, a "soul-less" (2) thing?}

In Part I, Defoe seeks to resolve the variety of inconsistent accounts in the press that referred to Peter's past and the circumstances of his discovery, with interpretations ranging from seeing Peter as an idiot, a lunatic, or a natural man lacking any reason and incapable of using his senses. Unable to speak, unmannered, apparently unaware of the world around him, Peter certainly seemed a marginal creature at the periphery of human society. The lack of language showed Peter's inability to express interior experience. In effect, the discovery of what is "interior" (interiority being understood as psychological and cognitive subjectivity) was of particular interest for eighteenth-century scholars. Hence, Peter is a "thing in human shape [...] without a soul" (1), in a condition which made common assumptions of both humans and animals look obscure. However, Defoe alludes to Peter's condition of marginality in relation to the state of civilized men and even in comparison with the condition of a wild man nurtured by mother nature: "He appears an object of mere uninformed nature, a life wanting a name to distinguish it, like a creature abandoned by nature itself" (5).

Peter's out-of-the-ordinary nature was particularly the effect of his soul-less condition. Peter could not reach the capacity to exercise the functions of a human subject, so he was "a body without the due exercise of a soul" (iv). The author critically inquires whether or not this "young nameless thing" (37) had a soul, a question which was the result of hot debates concerning the subject: Defoe echoed Locke's and Descartes' theory that man's essential nature was his rational soul (Willey 1986: 101).

Defoe's definition of the soul clarifies its importance for the discussion. The soul comprises the reasoning faculties of man, understanding, will, affection, desires, imagining and reflecting operations (23). When the rational part of man is taken away from him, he is unqualified to live (7) for "nothing can think which has no soul" (18). Because he manifested no clear signs of reasoning, Peter was assumed to have no soul, which made him act even below the brutes, or that his soul may be locked up and deficient in exerting itself properly (23). Even more, Peter's condition was worse than that of animals, because he seemed too passive, weak, foolish, fearful and defenceless to have been able to survive in the wild all by himself (8).

The possibility that Peter was a degenerated human is also considered. Thus, his adversity to humankind was also unnatural, because it did not correspond to the general natural law according to which all creatures will look for, and stick to, their own kind (21). Consequently, if Peter was neither a degenerate human nor an intelligent animal, this means that he was a "rude and uninformed creature" 
(21), or just a mere "object" (5), a "nameless thing" (37).

After carefully balancing all these conjectures, Defoe concludes that Peter's ambiguous human-animal condition could be the result of lack of improvement of his soul's faculties. Hence, the boy was in

"a state of mere nature, acting below the brutes, and yet we must grant him a soul: he has a body, in its shape human, the organick parts anatomically, we believe, the same as human; he acts the powers and motions of sensitive life, and of rational life, alike, as if they were confused and huddled together undistinguished" (23-24).

Defoe misses no opportunity for cultural criticism, so he also deplores the state of many fashionable women who were "mere empty shells, the beauteous shadows of nothing, an inanimate soul-less form" (2). Similarly, Peter was ignorant of the civilized society, but many eminent men of his age seemed to approach a state of uninformed nature by way of their intentional ignorance of reason (7). This way, the groups considered central to the civilized society were actually only theoretically so. In fact, Peter's case also echoed the discussions related to virtue in the eighteenth-century society. Defoe showed constant interest in representing unmanliness, pointing at the necessity of eighteenth-century men to offer models of virtue (Culea 2012: 540).

\subsection{The virtues of dumbness and deafness}

In Part II, Defoe discusses another topic prompted by Peter's situation, which was linked to the idea of fractured manliness, namely dumbness in politics. English courtiers and politicians were affected by the plague of dumbness, understood as being devoid of meaning (31). In fact, Peter is not less worthy of his title at court than the king's servants since the plague of dumbness affected politicians who were famous for "making long speeches, and saying nothing" (31).

Peter's inability to speak inspires the author to look for advantages of this disabling condition and he addresses aspects concerning human language and its roles in communication. For instance, in the ballad entitled On the Deaf and Dumb Being Taught to Speak (46-53), the satirist comments on the misery and inferiority of humankind as compared to animals in relation to the universality of their language, its rootedness in nature and the ease of communicating without any instruction. On the other hand, Peter's apparent deafness and dumbness saved him from suffering, keeping him away from the evils of society, thus adding to his innocence:

"The mind untainted, and untouch'd with crime,/Stands fitted to receive the true sublime,/Chaste from those crimes, which, by the ear or tongue,/Possess men's souls, and keep their hold so long" (52). 
Peter lacks those vices entertained by the civilized society, such as pride, ambition, avarice, rancour or malice, ungoverned passions, unbounded desires, so "how infinitely more happy he is than thousands of his more inform' $d$ and bettertaught fellow brutes in human shape" (43). As elsewhere, the conceptual metaphor of man as brute employed here underlines Defoe's scepticism of the superiority of humankind. Peter's former circumstance in the wild may have placed him in a marginal geographical and cultural position, but Defoe shows once again that several benefits render this condition as a more advantageous alternative to the so-called civilized one. Unfortunately, in case of such men of fashion, the benefits of knowledge and education are misused and lead to vice. In other words, instruction and knowledge acquisition mean nothing in the absence of virtuous behaviour.

Further on, the writer stresses the primary role of language for human existence: "words are to us the medium of thought, we cannot conceive of things, but by their names, and in the very use of their names" (38). Still, he reflects on that superior faculty of deaf and mute people which enables them to exercise their emotions and thoughts without the mediation of verbal language. Defoe sadly concludes that he would embrace deafness and dumbness, thus a condition perceived as marginal in society, if this brought a life without crime and $\sin (53)$.

\subsection{Education as the origin of perfectibility}

In Part III, Defoe expands his discussion about the nature of the soul as the originator of all human capacities, be they actions, emotions, or the ability to reason. The soul is the "operator" responsible for man's ability to "know, think, retain, judge, discern, distinguish, determine" (62), but all these are possible only with the support of instruction. Interest in man's education is centuries old and still is a topical subject because it is the unique gift which distinguishes men from brutes, "qualifying" and "finishing" (63) the human being.

On the other hand, the "Grand Negative" (63) in human life is the absence of education, a want which deforms the soul. Peter's situation clearly indicated that a man in a state of nature disproves the primitivists' theory, in that a man deprived of education or parental and social contact is doomed to be a damaged individual:

"nature requires the help of art to bring it to perfection of living: the soul is placed in the body like a rough diamond which needs polishing to show the perfect water of a true brilliant" (61).

Thus, in metaphorical terms, the soul is a diamond which needs the polishing of education to exert its capacities in full form, "because polishing the soul of man is an act of the highest consequence, and the chief thing that distinguishes him" (63). Education is the polisher of natural capacities and the foundation of erudition, the force which refines "the grand faculties of the soul" (63). The author insists on the necessity of early education for children because the soul and the 
"organic powers are as a lump of soft wax which is always ready to receive any impression" (61).

As a part of the discussion about the relation between nature and culture, Defoe shows that a mere state of nature is not the best option for human improvement. For Defoe, depravity in nature does exist, whereas virtues are acquired in the society of men (44). In this view, nature is presented as lack (Davidson 2009: 69) because nature outside culture is rough and imperfect, so "education seems to be the only specific remedy for all the imperfections of nature" (61). Moreover, at birth or in a pure state of nature, man knows neither vice nor virtue, and this condition makes him a dysfunctional individual placed outside the borders of the civilized, educated society. Once again, it is obvious that the key concept establishing these borders is education. The causes for Peter's inability to form sounds or words remained unknown, but Defoe believed that Peter differed from any other man "only in the loss it has sustained under so long a deny'd education" (60).

Defoe shows that man is born mute but not dumb, and he learns to speak by imitation because he has "a potential capacity to speak as soon as he can shape his mouth to form a sound articulate and distinct" (58). In other words, Defoe reinforces the common eighteenth-century theory which stated that, at birth, man is in a mere blank state, while education is the proper means of engraving his soul. Within the educational process, the role of instructors is also crucial because "man is a(s) rational, or a(s) stupid, just as he is handled by his teachers" (61). In his childhood, Peter did not have the possibility to improve his condition by means of education. At the other pole, many of his contemporaries from the noble society had this chance but, on account of their actions, they derided, denigrated and misused the benefits of learning:

"[...] and the fools which hate knowledge, should always go without it; as wisdom and virtue are their own reward, so vice and ignorance are their own punishment" (86).

Hence, as opposed to animals, uninstructed humans are "ten thousand times more miserable than a brute" (63).

\subsection{Foolishness or the failure of education}

In Part IV, the political satire is directed at the category of fools, including "politicians or statesmen" who are recognized among "the savages and wild creatures of the world" (88). Metaphorically, men turned into brutes whose destructive abilities engulfed Europe: "The Brute [...] is, indeed, a Devourer and Destroyer not of men, but of nations" (88). As a result of their lack of wisdom, they caused the fall of princes, the outbreak of wars, and the collapse of governments. Peter was considered to be a wild man or a savage, but the author claims that politicians are closest to savages, "ravenous and devouring", with an "unsatisfied appetite" for power (89). 
Defoe exposes the superficial and degraded foundations on which the civilized society was built, using the type of the fool, understood here as a person who acts unwisely, being unable to consider or judge things carefully or prudently. The author laments that fools succumb to passion and their love of pleasure. Peter really was a harmless fool who lacked the common powers of understanding. On the other hand, Peter's humbleness and lack of pretence could be symbolic of innate common sense and honesty, qualities which were unknown to men of fashion or political men.

As we have mentioned before, the degeneration of politics is also represented critically. Somehow, Defoe alludes to the reversal of the poles of power, with fools becoming central to the political machine. Fools were necessary tools in political dealings when it came to fraud, cheating, occupying positions, stealing money, etc. Unfortunately, in England it no longer made any difference if important positions were occupied by wise men or fools. In fact, all of Europe was ruled by state fools (89). Within the metaphorical spectrum, Defoe identifies more types of fools:

$\begin{array}{ll}\text { "Wise fools } & \text { Cunning fools } \\ \text { Natural fools } & \text { Unnatural fools } \\ \text { Silent fools } & \text { Prating fools } \\ \text { Knave fools } & \text { Rogue fools" (89) }\end{array}$

Politicians, statesmen and church fools are part of the last category, which is also the most dangerous. Except for politicians, other leading male figures in the socio-cultural sphere were also included in the typology of the fool, namely "the men of fashion", "the beaus", "assembly-men" and "wits" (96).

In Part V, Defoe comments on the usual causes of political corruption, impotence and failure in many European courts, which may also lead to national disasters. The most common error was that fools ruled instead of the king who did not take his position too seriously, so kings had to "learn the art of reigning without favourites" and "take pains to be kings (...) and govern by themselves" (113).

Two positive examples are given of European kings who resolved to administer the country without fools: the king of Spain excluded his foreign advisers and summoned only native politicians in his councils; in France, the king decided to take the full administration of his government into his own hands, even governing without a Prime Minister (114).

In the Conclusion, the author reiterates the objective of his work, that of denouncing the exaggerated or romanticized presentations of Peter's case by the foreign press or by the town talk. Defoe intended to rehabilitate Peter's state, showing that, most probably, he was not an idiot, a lunatic or a natural man lacking any reason (118) and expresses his hopes in the improvement of his condition through education.

However, if the wild boy's case made no object of satire for Defoe, the satirisation of his contemporaries' flaws certainly represented his second major objec- 
tive. Beaus, wits, politicians and statesmen lacked instruction, just as Peter did, though with different meanings, so they were also the object of pity because of their vanity, ignorance and pride (119).

Unfortunately, Peter did not prove capable of refining his intellect or his senses to the desired standards established by his tutors, so his royal patrons understood that he was doomed to remain in the same natural state all his life. As a result, he was removed from the royal court to the countryside where he was taken care of by a farmer. If Peter's mutilation at various levels of his personality was, in the end, a reason to be marginalized, the degradation of the leading figures of the day was even more lamentable as it showcased a great paradox of the enlightened age. Hence, despite its illuminated discourse, the age was pestered with the "affectation of wit" and "the perplexing throng of fools" like no age had been before (120).

Finally, Defoe makes an urgent call for rationality and morality as substitutes for the foolhardiness of the "men of mode" (iv) of this "pretended age" (119). It seems that the perfectibility of humanity and its entitlement to centrality among existing creatures could only be achieved through instruction at the levels of ethics, manners and reason.

Ironically, Defoe maintains that if Peter could show signs of improvement, this would certainly put the state fools at a greater disadvantage, widening the gap that existed between them. Peter might prove wiser after all and could be an object of imitation to those who "think no body so wise as themselves" (123). For Defoe, if this were possible, the poles of centrality and marginality would be reversed completely, with a wild man at the centre of society and its leading agents at the periphery. In other words, the wild creature would prove to be much more human than the "untaught animals of the present age" (123).

\section{Conclusion}

Peter's story, or that of feral children in general, leads us to various concluding remarks. Firstly, such cases still contain inexplicable aspects where human and animal natures intersect, puzzling our most common notions about human nature and society. Secondly, as Defoe shows, such a case also reflected the defects and inconsistencies of the eighteenth-century society. Defoe artfully criticizes the pretences of the enlightened society in matters of ethical, humanitarian, social or political characteristics, signalling that a state of nature can sometimes be a better alternative to that of culture when the latter is misused and abused. Perhaps what Defoe's text best signals is the degree to which the lack or deficient use of ethics and reason can cripple humanity. Thirdly, Peter's progression through education proved ineffective, and he could only move from a state of perfect wildness to one of debased humanity. The perfectly uninstructed Peter remained in a state of instinctual nature despite sustained efforts made to instruct him according to the norms of civilized society. Finally, he also failed to be a typical example of the 
noble savage type glorifying the laws of nature which were so much praised by the most important philosophers of the age. No matter what concluding aspect we may highlight, Defoe's text clearly lays emphasis on the significance of improvement for human nature, no matter what time or space we inhabit.

\section{Notes}

1 Biographical information about Peter the Wild Boy can be found in the following Internet articles: Moorhouse, Roger (2010) "Peter the Wild Boy." History Today 60 (4) http://www.historytoday. com/roger-moorhouse/peter-wild-boy, accessed May 1, 2012; Worsley, Lucy "Peter the Wild Boy." http://www.lucyworsley.com/courtiers/peter-the-wild-boy.html, accessed May 1, 2012.

2 National Geographic Documentary (2009) "Is It Real? Feral Children" http://www. dailymotion.com/video/xegxt7_is-it-real-natgeo-feral-children-1_shortfilms, accessed April $1,2012$.

3 Arbuthnot, John and Jonathan Swift (1726) The Most Wonderful Wonder that Ever Appeared to the Wonder of the British Nation, available at http://www.archive.org/stream/ lifeworksofjohna00aitk\#page/474/mode/2up, accessed May 1, 2012.

4 Defoe, Daniel (1726) Mere Nature Delineated: or, a Body without a Soul. Being Observations upon the Young Forester Lately Brought to Town from Germany. With Suitable Applications. Also, a Brief Dissertation upon the Usefulness and Necessity of Fools, whether Political or Natural. Printed for T. Warner, at the Black Boy, available at http://archive.org/details/ merenaturedeline00defo, accessed April 2, 2012. All quotations are taken from this text.

5 Kennedy, Maev (2011) "Peter the Wild Boy's Condition Revealed 200 Years after His Death." The Guardian, March 20, 2011 http://www.guardian.co.uk/artanddesign/2011/mar/20/peterwild-boy-condition-revealed, accessed June 5, 2012.

\section{References}

\section{Literary sources}

Arbuthnot, John and Jonathan Swift (1726) The Most Wonderful Wonder that Ever Appeared to the Wonder of the British Nation, available at http://www.archive.org/stream/ lifeworksofjohna00aitk\#page/474/mode/2up, accessed May 1, 2012.

Defoe, Daniel (1726) Mere Nature Delineated: or, a Body without a Soul. Being Observations upon the Young Forester Lately Brought to Town from Germany. With Suitable Applications. Also, a Brief Dissertation upon the Usefulness and Necessity of Fools, whether Political or Natural. Printed for T. Warner, at the Black Boy, available at http://archive.org/details/merenaturedeline00defo, accessed April 2, 2012.

\section{Books of criticism}

Culea, Mihaela (2010) "Breeding. A Partial History of the Eighteenth Century. By Jenny Davidson". The European Legacy. Toward New Paradigms 15 (5), 669-670, available at http://www. tandfonline.com/toc/cele20/15/5.

Culea, Mihaela (2012) "Defoe's Writings and Manliness: Contrary Men. By Stephen H. Gregg". The European Legacy: Toward New Paradigms 17 (4), 540-541, available at http://dx.doi.org/1 $0.1080 / 10848770.2012 .686976$. 
Davidson, Jenny (2009) Breeding: A Partial History of the Eighteenth Century. New York: Columbia University Press.

Fudge, Erica (ed.) (2004) Renaissance Beasts: Of Animals, Humans and Other Wonderful Creatures. Urbana and Chicago: University of Illinois Press.

Lamb, Jonathan (2004) "Review of: Julia V. Douthwaite, The Wild Girl, Natural Man and the Monster: Dangerous Experiments in the Age of Enlightenment". Eighteenth-Century Fiction 17 (1), 132, available at http://digitalcommons.mcmaster.ca/ecf/vol17/iss1/7, accessed April 24, 2012.

McFarland, Sarah E. and Ryan Hediger (eds.) (2009) Animals and Agency: An Interdisciplinary Exploration. Leiden: Koninklije Brill, Hotei Publishing.

Nash, Richard (2003) Wild Enlightenment: the Borders of Human Identity in the Eighteenth Century. Charlottesville, VA: University of Virginia Press.

Payne, Michael and Jessica Rae Barbera (eds.) (2010) A Dictionary of Cultural and Critical Theo$r y .2^{\text {nd }}$ edition. Malden, MA, USA and Oxford UK: Wiley-Blackwell.

Shinagel, Michael (1968) Daniel Defoe and Middle-Class Gentility. Cambridge, Massachusetts, MA: Harvard UP.

Willey, Basil (1986) The Eighteenth Century Background. Studies in the Idea of Nature in the Thought of the Period. London and New York: Ark Paperbacks.

\section{Internet sources}

Kennedy, Maev (2011) “Peter the Wild Boy's Condition Revealed 200 Years after His Death”. The Guardian, March 20, 2011. http://www.guardian.co.uk/artanddesign/2011/mar/20/peter-wildboy-condition-revealed, accessed June 5, 2012.

Lane, Megan (2011) “Who Was Peter the Wild Boy?” BBC News Magazine, August 8, 2011 http:// www.bbc.co.uk/news/magazine-14215171, accessed June 28, 2012.

Moorhouse, Roger (2010) "Peter the Wild Boy". History Today 60 (4) http://www.historytoday. com/roger-moorhouse/peter-wild-boy, accessed May 1, 2012.

National Geographic Documentary (2009) "Is It Real? Feral Children". http://www.dailymotion. com/video/xegxt7_is-it-real-natgeo-feral-children-1_shortfilms, accessed April 1, 2012.

Worsley, Lucy "Peter the Wild Boy". http://www.lucyworsley.com/courtiers/peter-the-wild-boy. html, accessed May 1, 2012.

Minaela Culea is PhD Lecturer of English language, literature, culture and civilization at the Faculty of Letters of Vasile Alecsandri University of Bacău, Romania. In 2008 she completed her PhD thesis in literature at Al. I. Cuza University of Iași, Romania. Her research interests include eighteenth-century English literature and culture, cultural studies, Anglophone and British culture and civilization, the history of Great Britain and European discourse.

Address: Mihaela Culea, Department of Foreign Languages and Literatures, Vasile Alecsandri University of Bacău, 8 Spiru Haret, Bacău, 600114, Romania. [email: culea.mihaela@ub.ro] 
